\title{
THE BEGINNINGS OF THE PREŠOV GREEK CATHOLIC EPARCHY DURING THE EPISCOPACY OF ITS FIRST BISHOP GREGOR TARKOVIČ 1
}

\author{
Jaroslav Coranič
}

DOI: 10.17846/CL.2020.13.2.176-186

\begin{abstract}
CORANIČ, Jaroslav. The Beginnings of the Prešov Greek Catholic Eparchy During the Episcopacy of Its First Bishop Gregor Tarkovič. The Greek Catholic Eparchy of Prešov was canonically erected by Pope Pius VII on September 22, 1818. From its inception until 1841, the eparchy was administered by Bishop Gregor Tarkovič upon whose shoulders rested a great responsibility for the organization of the newly erected eparchy. Over the course of his episcopacy, Bishop Tarkovič secured the establishment of all essential eparchial institutions: the bishop's office, the Chapter, the eparchial archives, the library, etc. Bishop Tarkovič also greatly contributed to resolution of several economic and financial issues concerning the overall administration of his eparchy. Above all, worth noting is his effort in obtaining benefices and establishment of proper eparchial funds. The article introduces the journey of Bishop Tarkovič that was dominated by his undying love for learning, diligence and yearning for solitary and ascetic life. Despite this composition of his being, Bishop Tarkovič will be remembered for his remarkable achievements in laying sound foundations for the future direction and development of the Greek Catholic Eparchy of Prešov.
\end{abstract}

Keywords: Greek Catholic Church, Metropolitan Church sui iuris, Greek Catholic Eparchy of Prešov, Relata semper, Gregor Tarkovič

In 2018, the Greek Catholic Metropolitan Church sui iuris in Slovakia celebrated the bicentenary of the establishment of the Prešov Eparchy. Elevated to the archeparchy today, the historical Eparchy of Prešov constitutes an institutional foundation for all Greek Catholics living in the territory of Slovakia.

The Greek Catholic Church is an Eastern Christian particular church, which is in full union with the Catholic Church. Its mission is identical with that of the Roman Catholic Church; the main difference is in the celebration of the liturgy. The Greek Catholic Church maintains its rich Eastern theological and liturgical tradition and Byzantine ceremonies. Mentality of Greek Catholics is Eastern, yet their ties with Rome are very strong. They live in the Oriental model similar to Eastern Orthodox, but their Church is in full communion with the Apostolic See in Rome. It has preserved some original traditions that are no longer present in the Latin Church. The history of the Greek Catholic Church shows that it is possible to maintain own particularity without breaking the unity. Through evangelization, Saints Cyril and Methodius ${ }^{2}$ developed a model of ecclesiastical life that connects the richness of the Oriental tradition in canon law,

1 The article is an output of the research project VEGA 1/0448/18 conducted within the framework of the Scientific Grant Agency of the Ministry of Education of the Slovak Republic.

2 For more detail on Cyrillo-Methodian phenomenon in Slovak history from religious, national and cultural perspectives see: Hetényi 2019, 141-158. 
liturgy, theology, and spirituality with the principles of the One, Holy, Catholic and Apostolic Church in full communion with the Bishop of Rome (Valčo - Slivka et al. 2010, 261).

The responsibility for leading and organizing the new Greek Catholic Eparchy of Prešov was entrusted to its first bishop, Gregor Tarkovič. Gregor Tarkovič was born on November 19, 1754 to Andrej Tarkovič and Anastázia, nee Hankovská, in a village of Pasika, a filial of the Greek Catholic parish of Suskovo, in the Bereg County (present-day Zakarpattia Oblast in Ukraine) (Duchnovič $1877,54)$, where his father was a cantor.

Tarkovič graduated from the Gymnasium of the Jesuit Fathers in Uzhhorod. He was a remarkably gifted, diligent, and pious student who maintained a high level of academic performance throughout his studies. Upon completing his secondary education, Tarkovič decided to enter the Society of Jesus. His desire remained unfulfilled due to historical circumstances. Just before entering the novitiate, the Jesuit Order in Vacz had been dissolved, so Tarkovič decided to continue his study of philosophy in Velký Varadín (present-day Oradea Mare). In 1775, Bishop of Mukachevo, Andrej Bačinský sent him to a newly established St. Barbara Seminary (Barbareum) in Vienna to pursue higher theological studies, which he completed in 1778 (Duchnovič 1877, 55).

After successfully completing his theological studies with high honours, Tarkovič returned to Mukachevo. Bishop Bačinský ordained him a subdeacon on November 9, 1788. On November 20 of the same year, Tarkovič was ordained a deacon. On New Year's Day of 1779, he received the holy orders of priesthood from Bishop Bačinský in the monastic church of the Basilian Fathers on Chernecha Hora (Ruby 1898, 24-25).

After his ordination, Bishop Bačinský immediately appointed Tarkovič Professor of Theology in the Eparchial Seminary in Uzhhorod, where he remained until 1793. In the same year, Tarkovič assumed the duties of a parish priest in Hajdudorog, but he did not stay there for long. In 1797, he was transferred to the Uzhhorod parish where he fulfilled his office of pastor until 1803 (Lacko 1982, 14).

In 1803, Tarkovič was appointed as the official censor of Slavic books at the Royal Printing House in Buda (known as the Illyric Printery) (AGAP, c. KV, inv. no. 90, sign. 168). In 1804, while still in Buda, Tarkovič was promoted to the Canon of the Mukachevo Chapter. In 1803 and then in 1807, the Chapter deputized him to the National Diet in Bratislava (Pekar 1968, 12). As an official censor, Tarkovič spent ten years in Buda. He occupied one room at the monastery of Capuchin Fathers devoting his time to prayers and books (Murín 1943, 36).

In July 1813, the Mukachevo Chapter appointed Tarkovič Vicar General of Košice Vicariate with its seat in Prešov. The Hungarian Supreme Royal Council confirmed his appointment. The unfinished work in Buda and Pest kept Tarkovič from coming to Prešov before December 18, 1813. Tarkovič spent two years in Prešov, living in the old and dilapidated monastery of the Minorite Fathers. On December 20, 1815, Capitular Vicar Michal Bradáč of Mukachevo passed away. Following his death, the Chapter appointed Gregor Tarkovič his successor. It was December 22, 1815.

On November 3, 1815, Francis I, on his own initiative, issued a decree that confirmed the division (divisio) of the Eparchy of Mukachevo. The Court Chancery informed the Hungarian Supreme Royal Council about the emperor's decision and requested the Council to propose precise border demarcation and the exact number of parishes that were to be incorporated into the newly established eparchy. Moreover, the Council had to nominate suitable candidates to fill the both episcopal sees (Prešov and Mukachevo). The Council set up a special committee responsible for selecting the right candidates. The committee first met in Buda on January 16, 1816 (Duchnovič 1877, 35).

The committee proposed that the new eparchy territorially corresponded to the territory of the Košice Vicariate and included parts of seven different counties: Abov, Boršod, Šariš, Spišs, 
Turňa, Gemer, and a northern part of Zemplín (Stropkov, Vranov, Humenné, Medzilaborce and Hostovice deaneries) comprising 194 parishes in total (this solution was based on that adopted by the Mukachevo Chapter in 1810) (Pekar 1967, 89; Kubinyi 1970, 84). ${ }^{3}$

At the following meeting on January 26, 1816, the committee proposed Canons Alexej Pócsy and Simeon Bran, members of the Chapter of Velký Varadín as candidates for bishop appointments in the Mukachevo Eparchy and Capitular Vicar Gregor Tarkovič and Canon Ján Olšavský (newly appointed Eparchial Vicar of Prešov) for bishop appointments in the Eparchy of Prešov (Duchnovič 1877, 36). The emperor approved the proposed solution for the detachment of the parishes and nominated Alexej Pócsy and Gregor Tarkovič as the most suitable candidates for bishops. On February 6, 1816, the emperor informed the Mukachevo Chapter. In his letter to Rome, dated March 1, 1816, Francis I briefed Pope Pius VII about his decision to divide the Eparchy of Mukachevo and erect a new eparchy in Prešov. At the same time, the emperor asked the pope to approve his decision and confirm the appointment of the bishop candidates (Pekar 1967, 89; Kubinyi 1970, 85).

Not waiting for an answer from the Holy See, Francis I appointed Pócsy the bishop of Mukachevo, and Tarkovič the bishop of Prešov (Kubinyi 1970, 85; Welykyj 1954, 337-339; Lacko 1982, 21; Vasil' 2000, 47). The letter of appointment addressed to Bishop Tarkovič contained no mention of the eparchial seat or financial provision for either the eparchy or the bishop. This led to several discrepancies delaying the process of the canonical erection of the Eparchy of Prešov.

Gregor Tarkovič did not show much "enthusiasm" at first. After all, he was appointed without the approval of the Apostolic See. Besides that, Tarkovič was familiar with the local conditions in his eparchy, since he had served as Eparchial Vicar in Prešov (June 30, 1813 - December 22, 1815). Especially the dilapidated residence and the cathedral church were of his great concern. In his decision to establish a new eparchy, Emperor Francis I did not touch upon financial affairs, despite the standard practice. On May 11, 1816, Tarkovič therefore decided to decline this nomination under the pretext of ill health and advanced age - he was 62 at that time (Duchnovič 1877, 38). On October 29, 1816, the Hungarian Supreme Royal Council asked Tarkovič once again to either confirm or refute his decision regarding his appointment. If he were to refuse the nomination, the Council needed to propose a new candidate. Eventually, Tarkovič accepted the appointment on condition that the financial provision of the eparchy would be resolved immediately. The Hungarian Court Chancery addressed this matter and proposed to allocate some financial means to cover bishop's pension and any expenses related to the reconstruction of the bishop's residence and the purchase of liturgical items. The money was to be used to finance charitable and educational funds, too. The Chancery decided that the eparchy was assigned some immovable property to provide a stable income without the need for state subsidies. This proposal was then referred to the emperor. On July 11, 1817, Francis I issued a deed of donation (AGAP, c. Listiny, inv. no. 1, sign. 8806) for the newly erected Eparchy of Prešov in which he confirmed Tarkovičss appointment as the bishop of Prešov. Francis I ordered to transfer $50 \%$ of the state subsidy, received by the Eparchy of Mukachevo, to provide for the new eparchy, including the Chapter of Prešov (AGAP, c. Listiny, inv. no. 1, sign. 8806). The emperor, however, did not respond to all requests presented by the Chancery, which left Bishop-Elect Tarkovič unhappy with the solution. The reconstruction of the bishop's residence remained the most pressing issue. At that point, Tarkovič had not received any confirmation from Rome regarding the establishment of the new eparchy or his own appointment as a new bishop. He decided to take the matter into his own hands and travel to Vienna. Having no financial resources (the money that he was granted by the emperor was to be placed at his disposal

3 A. PEKAR refers to the Vatican Archive of the Consistorial Congregation, year 1818, P. II., f. $237^{\text {a-b }}$, referring to about 194 parishes, J. KUBINYI mentions 192 parishes. 
as soon as he took the oath to his office) Tarkovič was living in poverty in Vienna for three long years. Yet, he succeeded in taking necessary steps to secure provision of his eparchy. On September 30, 1817, Francis I instructed to pay the subsidy of 30,000 florins to both the Eparchy of Mukachevo and Prešov. The monies were to be distributed proportionally to both eparchies and used as an endowment for different religious funds (Educational Fund to provide for seminarians; Fund for orphans and widows of deceased priests, etc.). ${ }^{4}$ The emperor also ordered to commit funds to the reconstruction of the residence and the cathedral. This money was to be available after the bishop's enthronement (Duchnovič 1877, 42). On April 17, 1818, the emperor offered Bishop-Elect Tarkovič the possession of a former Camaldolese monastery Červený kláštor in a village of Lechnica in Spiš County, as the benefice (Duchnovič 1877,44 ). Due to red tape, many of these ordinances would have come into effect after the bishop's return to Prešov in 1820 .

Earlier we mentioned that Francis I did not wait for the Holy See to approve the division of the Eparchy of Mukachevo and confirm the newly appointed Greek Catholic bishops. Besides that, the emperor's request dated March 1, 1816 lacked some concrete information about this matter. That is why Pope Pius VII authorised the Consistorial Congregation to investigate. The Consistorial Congregation requested the Apostolic Nunciature in Vienna to provide the missing information. The investigation did not proceed apace. The Nuncio learnt that Empress Maria Theresa removed the seat of the Mukachevo Eparchy to Uzhhorod in 1775 without the prior approval of the Apostolic See. The new fact posed a question about the proper name of that eparchy. Was it still the Eparchy of Mukachevo or was it the Eparchy of Uzhhorod? ${ }^{5}$

On July 24, 1817, Pope Pius VII confirmed the removal of the eparchy's seat to Uzhhorod and granted "sanatio in radice" for all acts performed in this regard. The pope also declared that the Eparchy of Mukachevo would retain its original name (Welykyj 1954, 326).

Bishop-Elect Tarkovič remained in Vienna because the process of the canonical erection of the Eparchy of Prešov had not been finalized at that point. To accelerate the whole process, Tarkovič requested all necessary documents concerning the division of the eparchy from the Mukachevo Chapter. The materials Litterae testimonials were drafted by the Chapter on October 16, 1817 and subsequently forwarded to Tarkovič. On February 14, 1818, Nuncius Leardi contacted again the Chancellor of Vatican and reminded him that Emperor Francis I had approached the Holy See about the canonical erection of the Eparchy of Prešov and confirmation of Tarkovičss appointment as a new bishop as early as March 1, 1816 (Kubinyi 1970, 87-88).

The process of the canonical erection of the Greek Catholic Eparchy of Prešov could finally commence. On August 7, 1818, in the presence of two witnesses, Gregor Tarkovič took the oath of fidelity to the Catholic Church into the hands of the Apostolic Nuncio and made profession of faith. On September 9, 1818, the Consistorial Congregation issued a decree establishing the Eparchy of Prešov. A few days later, on September 19, 1818, Secretary Rafael Monius, presented the content of the papal bull for the first time in front of the congregation of faithful. The bull

4 The Supreme Royal Council authorized both eparchies to divide the endowment and funds on March 1, 1816. On October 24, 1820, the Council enforced his Majesty's decree issued in 1817.

5 Initially, the seat of the Eparchy of Mukachevo was housed the Basilian monastery of St. Nicolas located on Chernecha Hora near Mukachevo. In 1751, Bishop Michal Manuel Olšavský moved his residence to Mukachevo, to the house he had built with a financial support from Empress Maria Theresa. In 1775, the seat of the eparchy was moved again, this time to Uzhhorod (the eparchy was still known as the Eparchy of Mukachevo). The bishop's residence was housed in the former Jesuit College. Officially, the bishop's office and other institutions commenced their activities after the consecration of the cathedral on October 15, 1780. Following the death of Bishop A. Bačinský, some experts in canon law raised serious doubts and asked whether moving the bishop's residence without the prior consent of the Holy See was indeed in line with the canon law. The matter was then forwarded to the Holy See for consideration. 
Relate semper (AGAP, c. BA, inv. no. 454, sign. 442), named after its opening line, was solemnly promulgated on September 22, 1818 and confirmed by Pope Pius VII at the meeting of the Consistorial Congregation on October 2, 1818 (AGAP, c. Listiny, inv. no. 6, sign. 137; Zouhar 2018, 153).

After issuing the founding bull, Pope Pius VII also issued a letter of appointment for Gregor Tarkovič, the first Greek Catholic bishop of Prešov, and handed him jurisdiction over the newly established eparchy. On October 6, 1818, the pope also issued two other documents. One of them was addressed to the clergy and faithful of the eparchy. The last from the series of decrees was the concordat defining the relationship between the Greek Catholic Eparchy and Rome (Coranič $2018,111)$.

The papal bull Relate semper was not expedited straightaway because the Holy See wanted to secure the payment of all costs related to the issue of the bull. Interestingly enough, the payment of 1,055 florins was addressed to Bishop Tarkovič, although it was a common practice that the state settled the expenses in similar cases. Having no financial resources, Bishop-Elect Tarkovič approached the Apostolic Nuncio in Vienna on February 5, 1819. He explained that there was no way he could pay the requested sum and offered his resignation. The Nuncio informed the government officials. On April 4, 1819, Chancellor Klemens Metternich announced that the government made a commitment to pay all the expenses (Kubinyi 1970, 91).

Financial problems that Bishop-Elect Tarkovič encountered during his stay in Vienna did not seem to disappear. Having thoroughly examined the documents related to the possession of Červený Kláštor, Tarkovič learnt that the stipulated income of 11,692 fl. and $42 \mathrm{cr}$. was in fact a little less than 4,000 florins. This amount could hardly be enough to maintain the residence, the cathedral church and pay the Canons (Coranič 2018, 111-112).

While Bishop-Elect Tarkovič was still in Vienna, the Eparchial Chapter in Prešov was formed. Francis I announced his intention to form the Chapter as early as February 6, 1816. In line with the stipulation in Relata semper, the Chapter was approved and canonically erected by Pope Pius VII on September 29, 1818. Having established the financial provision for the Chapter, the resolution of the emperor was promulgated on May 16, 1820 (Schematismus 1931, 13). The members of the Chapter were formally installed on August 6,1820 in the cathedral that formerly belonged to the Eparchial Vicariate. At the ceremony, the papal bulls and royal decrees related to the establishment and provision of the eparchy and the Chapter and to the elevation of the vicarial church to the cathedral were read. On that very day, the process of the canonical erection of the Eparchy of Prešov was officially concluded. Everybody impatiently awaited the arrival of Bishop-Elect Gregor Tarkovič from Vienna. During his absence, the administration of the eparchy rested on Capitular Vicar Ján Mehay (Šturák 1999, 28).

Having solved all the matters concerning the eparchy, Tarkovič visited Apostolic Nuncio on September 10, 1820 and decided to come back to Prešov. On his return, Tarkovič paid a visit to the Archbishop of Esztergom and Primate, Alexander Rudnay (he moved his residence from Trnava to Esztergom in 1820) and stopped in Buda. In Miškolc, Tarkovič fell ill and in such an unfortunate state, he arrived to Prešov on November 7, 1820. In Prešov, he found his residence desolate, in far worse condition than he had left it several years before. In these "ruins", he spent the rest of his life with great patience and ascetics (Duchnovič 1877, 52).

Having recovered from the illness, Bishop-Elect Tarkovič started to consider his episcopal consecration. He was confirmed by both His Majesty and Pope Pius VII but was not consecrated and could not assume the administration of the newly erected Eparchy of Prešov. Having realized that a big ceremony would involve a lot of money and taking into account his poor health, Tarkovič decided on a simple and quiet ceremony at the Monastery of the Basilian Fathers in Krásny Brod. He was consecrated on June 17, 1821 in the presence of the Canons of his Chapter and his clergy. 
The main consecrator was Bishop of Mukachevo, Alexej Pócsy (AGAP, c. BA, inv. no. 338, sign. 404). At the ceremony, Tarkovič professed the Catholic faith and took the oath (AGAP, c. BA, inv. no. 338, sign. 691). Returning to Prešov, he was privately installed in the Cathedral of St. John the Baptist and assumed administration of his eparchy, which until then was governed by Vicar Capitular (AGAP, c. BA, inv. no. 338, sign. 4691).

After his formal installation in June 1821, Bishop Tarkovič began to govern his eparchy by establishing essential eparchial institutions starting with the bishop's office. It consisted of Secretary (Bazil Popovič was Tarkovičs right-hand man from 1822 until October 2, 1837 when he was appointed Bishop of Mukachevo), archivist, actuary, chancellor, and librarian. The Episcopal Consistory, an advisory body to the bishop, was composed of five priests (Pekar 1968, 8; Pirigyi, 1990, 76).

Hungarian Primate Alexander Rudnay held a great national synod in Bratislava (September 8 to October 15, 1822). The provincial synod was to be preceded by individual diocesan synods. On November 18, 1821, Bishop Tarkovič held his first eparchial synod in Prešov. In addition to the Chapter and the consistorial clergy, deans from all seventeen deaneries and other delegated priests participated. The Basilian Fathers (who had two monasteries in the eparchy - in Krásny Brod and Buková Hôrka) were also represented. The synod, however, did not live up to bishop's expectations. His poor health did not permit him to attend the synod in person, so he sent Bazil Popovič instead. Since the bad weather prevented many invited priests from attending, the synod was held only in the presence of the Prešov clergy and some Basilians fathers. In accordance with Primate Rudnay's orders, the acts of the synod were then sent to the National Synod of Hungary in Bratislava (AGAP, c. BA, inv. no. 338 , sign. 628 ).

At their meeting in Bratislava, the Hungarian body of bishops discussed several measures with the aim to improve religious life and tighten discipline of secular clergy and members of religious orders. Bishop Tarkovič was not able to take part due to his ongoing illness. The Prešov eparchy was represented by Bishop of Mukachevo Alexej Pócsy (Vasil 2000, 162). The synod also dealt with issues directly affecting everyday lives of Greek Catholics, among them the adoption of the Gregorian calendar (Špirko 1943, 352).

Although the government did not allow official announcement of the synod resolutions, Bishop Tarkovič made every effort to implement them in his eparchy. In his first circular letter, he urged his priests to live religious and pious lives, both at work and at home. He knew very well that the religious life of the faithful reflected spiritual and educational level of the clergymen. The status of the Greek Catholic Church depended on that as well. Educational level and spiritual maturity of the faithful in Tarkovič's eparchy were low. The main problem was the lack of schools, since the majority of public schools established by Bishop Bačinský was located in the Eparchy of Mukachevo. Preaching in most churches was limited to feasts and holy days.

Besides the inherited faith, customs, and traditions, Greek Catholics also observed many local superstitions. It was said about them that "Ruthenos sine superstitionibus, nec feliciter nosci, nec pie vivere, nec beste mori posse (It would be difficult for Rusyns to come into this world, live piously or die blissfully without superstitions)" (Bidermann 1867). Bishop Tarkovič wanted to rid his flock of superstitions and witchcraft that had spread everywhere at the expense of the authentic religious life and true faith. From the very first days of his episcopacy, Bishop Tarkovič encouraged his priests to combat this sad and evil pagan legacy (ACS VZ, 2.10.1821). Newly established public schools were to be instrumental in uprooting these pagan traditions. In another circular letter issued in 1827, Bishop Tarkovič demanded from his priests to provide detailed information about suitable buildings that could be turned into schools, about persons suitable to fill positions of teachers and about possibilities to cover the purchase of schoolbooks (ACS VZ, 7.3.1827). From 1828 onwards, 
Bishop Tarkovič established public schools that were run by pastors of local churches. Teachers, however, were appointed by school inspectors.

Throughout the course of his episcopacy, Bishop Tarkovič found himself enmeshed in many difficulties regarding an uneasy relationship between some clergy and cantors (teachers) and tension among the clergy. Disputes between priests over benefice were not uncommon either. To correct the situation, Bishop Tarkovič issued “The Statutes of the Prešov Eparchy" comprising of thirteen articles. The Statutes, partially adopted from those of the Eparchy of Mukachevo, were amended and complemented by Tarkovič himself. The Statutes addressed the transfer of a priest from one parish to another and harmonised the so-called parochial year with the civil one. The Statutes also stipulated the portion of the harvest that the faithful should donate to their priests (as benefice). The respective deans were to oversee the process (ACS VZ, 5.10.1822). To settle the conflict between priests and cantors, Bishop Tarkovič introduced a scheme dividing the income between these two groups (ACS VZ, 10.4.1824).

In his episcopal circular letters, Bishop Tarkovič urged the clergy to be diligent in performing their duties and in keeping the parish books, especially then the parish registers, in order. He ordered deans to revise and audit the books in the presence of custodians and elders. Annually, the revised register books were sent to the bishop's office for verification (Murín 1943, 42).

In other circular letters, Bishop Tarkovič addressed several administrative issues within the authority of priests in individual parishes. Generally speaking, the clergy was not sufficiently educated in these matters that often lead to misunderstandings between the bishop and his faithful. For instance, Bishop Tarkovič introduced "cash" ledgers in which the priests were asked to enter all receivables and payables (ACS VZ, 2.10.1821, 7.3.1827, 29.7.1829).

Bishop Tarkovič ordered priests to keep detailed inventories from which the actual state of parish buildings, churches, movable and immovable property could be ascertained. Many parishes had not kept any inventories before (Murín 1943, 44).

In the following circular letter, issued on December 1, 1835, Bishop Tarkovič ordered priests not to store any property of perishable nature. They were advised to cash it instead (ACS VZ, 1.12.1836).

Tarkovič wanted his priests to become familiar with keeping account books and inventories. From 1836, all incoming priests were not allowed to take over their new parishes unless the full inventory of church and parochial property was compiled. It had to be done in line with a set of rules specified by the bishop and signed by the respective dean (Murín 1943, 44).

Bishop Tarkovič renewed several ordinances of Bishop Bačinský. Under one of such ordinances, priests were allowed to commission craftsmen and artists to build churches and altars or work on paintings and interior decorations only with a prior consent of the bishop's office. This was to prevent construction and artistic work being carried out by non-professionals. If a priest had commissioned an unauthorized craftsman or artist, he was not permitted to pay their wages from the church treasury. He had to cover the expenses from his own pocket (ACS VZ, 22.7.1825).

Bishop Tarkovič truly cared for his clergy. In 1823, he helped to finalise the issues pertaining to the foundations of public eparchial funds. Although the foundations had already been established by the decree issued by the Hungarian Supreme Royal Council ${ }^{6}$ three years earlier, they presented only a temporary and insufficient solution (Duchnovič 1877, 61-62).

6 The Hungarian Supreme Royal Council (translated also as the Vice-Regal Council), Consilium regium locum tenentiale Hungaricum, Magyar Királyi Helytartótanács.

The origins of this institution date back to the turn of the 15th and 16th century. It was the highest administrative body in Hungary that was formed from the Hungarian Council and the office of the Palatine. Initially, the Supreme Royal Council's purview was to deal with judicial matters; later its mandate 
The Seminary Fund was used to provide for education of seminarians from the Prešov Eparchy in other dioceses' seminaries, since there was no seminary in the Prešov Eparchy at that time. In keeping with the conclusions of the Council of Trent, bishops were ordered to establish a seminary to train young men for priesthood. A directive issued by the Congregation for the Propagation of Faith on November 16, 1818 revoked the ruling of the Trent Council and the original has remained binding only for bishops of the Latin Rite. In the eparchies of the Byzantine Rite, there were no seminaries. It was a commonplace for the sons of married priests to become their successors. They received the fundamental theological and liturgical education at home. The young candidates to priesthood studied theology and practised religious life in monasteries, which were often bishops' residences, or were sent to the Latin Rite seminaries and received the sacrament of Holy Orders there. On that account, the Congregation de Propaganda Fide did not insist that Eastern Rite bishops established theological seminaries (Kubinyi 1970, 95-96). The first seminary for the Prešov Eparchy was therefore established as late as 1880 by Bishop Ján Vályi.

After the establishment of the Prešov Eparchy, a majority of seminarians studied at the Eparchial Seminary in Uzhhorod. In 1823, the Supreme Royal Council issued its decision to divide the foundation for education of clergy between the Mukachevo and Prešov eparchies. There were 32 seminarians to be provided for and educated as follows:

1) 2 seminarians in the Central Seminary in Pest,

2) 5 seminarians in the Primatial Seminary in Trnava,

3) 3 seminarians in the Imperial Monastery in Vienna,

4) 10 seminarians in the Eparchial Seminary in Uzhhorod,

5) 12 seminarians in various institutions provided for from other funds (Ruby 1903, 16).

Among Bishop Tarkovič’s greatest contributions was the foundation of two new institutions, the eparchial library and archives.

Roman Catholics, followers of the Latin liturgical rite, played an important role in enhancing cultural, religious and spiritual lives of Greek Catholics. The coexistence of Catholics of Latin and Byzantine rites, however, brought many inter-ritual problems. In 1802, the Apostolic See in Rome called on Roman Catholic and Greek Catholic bishops to settle their differences and stop interfering in administration of the other's diocese (ACS VZ, 13.6.1802). The conversion from one rite to another (mostly converting from the Eastern to Latin rite) proved rather problematic. In regions with predominant Roman Catholic population, the priests often "usurped" the Greek Catholic faithful and "won them over" for the Latin rite. This course of action created tension between the followers of the two rites, as described by Secretary Bazil Popovič in his report to

was much broader. In 1673, the Supreme Royal Council ceased to function for some time. Following the Hungarian Diet's adoption of the Pragmatic Sanction in 1723, the Council was reorganized and became known under its Latin name Consilium regium locum tenentiale Hungaricum. In 1785, the seat of the Supreme Royal Council was removed from Bratislava to Buda. It was composed of twenty-two councillors and one inspector, who received their positions through royal appointments, and lower civil servants who were appointed by the Hungarian Council. The Supreme Royal Council was presided by the Palatine or, in case of vacancy, by a Viceroy. Gradually, several sections and permanent commissions were established to oversee the various branches of administration. One of such commissions - the ecclesiastical (religious) commission was responsible for allocation of endowments to individual bishoprics, treasuries of the clergy or educational (scholarship) funds. The Supreme Royal Council carried out the king's decrees and oversaw the entire internal administration and governance of the country, with the exception of financial and judicial matters.

See also: Darina Lehotská (1972, 250-255), Karel Malý and Florián Sivák (1992, 208). 
Bishop Tarkovič on March 15, 1825 (AGAP, c. BA, inv. no 341, sign. 300; AGAP, c. BA, inv. no 345, sign. 768).

Growing inter-ritual problems brought Latin and Greek Catholic hierarchs, Bishop of Prešov and Archbishop of Eger to negotiate an agreement. The agreement stipulated standards that the clergymen of both rites were obliged to follow. The negotiations took place in 1828. Archbishop of Eger informed about the results in his circular letter issued on 10 November. Bishop of Prešov followed with his circular letter issued on 31 December (Vasil 2000, 165). The latter clarified that in order to renew the ritual harmony he had negotiated with Archbishop of Eger some very specific rules and provisions to be followed in situations when a person decided to convert from one rite to another. Bishop of Mukachevo and Archbishop of Eger discussed this agreement too, at their meeting held in 1829. The conclusions of the meeting came to be known as Conventio gr. r. c. Munkacsiensis cum Eppis l. r. Szatmariensi et Casoviensi (Vasil' 2000, 165). These regulations were expected to correct the situation, but they did not bring the desired inter-ritual harmony (ACS VZ, 9.5.1829).

During his episcopacy, Bishop Tarkovič became embroiled in an 1831 peasant rebellion. Throughout the whole period of the cholera epidemic, Bishop Tarkovič kept sending letters and circulars to all archdeaneries in his eparchy, in which he informed archdeans, deans, priests and the Greek Catholic faithful about the anti-epidemic measures and treatment methods. Fifteen priests died of cholera in the Eparchy of Prešov alone. The death toll from this outbreak among the Greek Catholics is unknown, since the mortality reports that have been preserved are not complete. Nevertheless, we can still establish the average mortality rate in the Prešov Eparchy at $5.21 \%$. Based on this figure, the number of cholera victims from among the Greek Catholics can be roughly estimated at 9,000 (Liška 2012, 102-103).

Bishop Tarkovič was a spiritual and pious man living a simple ascetic life. When confronted with problems concerning financial matters pertaining to administration of his office, Tarkovič struggled. Although not endowed with great organizational skills, the bishop still took care of material provision for his eparchy. That also included the reconstruction of his residence (Duchnovič 1877, 58).

As mentioned above, the abolished monastery of the Minorite Fathers was in a deplorable condition. There were no doors or windows. The shingle roof was rotten and leaky. Bishop Tarkovič had tried to secure the restoration of his residence when he lived in Vienna. On July 8, 1824, Bishop Tarkovič turned to Francis I and insisted on proposing new plans for its restoration (AGAP, c. BA, inv. no. 340, sign. 824). The emperor did so in 1826. The new budget (AGAP, c. BA, inv. no. 342, sign. 1153), however, significantly exceeded the original one from 1817. The Supreme Royal Council proposed that Bishop Tarkovič provided the additional expenses from his own treasury (AGAP, c. BA, inv. no. 343, sign. 1321). The bishop informed the Council that he was unable to contribute to the restoration because of his poor income. The Council ordered to accommodate the blueprints to the previously assigned sum. While the new plans were being proposed, rejected and finally approved, the roof over the corridor in the southern part of the building collapsed in 1830 (Duchnovič 1877, 66). Exposed to rain and inclement weather, the residence soon deteriorated. There was a danger that the whole building would collapse. For safety and aesthetic reasons, the Supreme Royal Council ordered to demolish the whole building, with an exception of its rear part occupied by the bishop and his assistants (Duchnovič 1877, 67).

Adapting the cathedral for the use of the Byzantine rite was not an easy task either. The money assigned to the eparchy for this purpose covered only the reconstruction of two side chapels (Schematismus 1931, 16-17). Despite the great effort, Bishop Tarkovičs desire to reconstruct the residence and adapt the cathedral for the use of the Byzantine rite remained unfulfilled. 
Bishop Tarkovič had to live in such conditions for over 20 years. His strong spirit that did not yearn for earthly possessions, comfort, and social life enabled him to endure the hardship. To fulfil these Tarkovičs desires was the task of his successor on the episcopal see, Jozef Gaganec who took care of residence reconstruction and adaptation of the cathedral for the use of the Byzantine rite.

Bishop Gregor Tarkovič died on January 16, 1841. Vasil Popovič, Bishop of Mukachevo, celebrated the archijerej divine liturgy for the repose of Tarkovičss soul in the Greek Catholic cathedral in Prešov. The first Greek Catholic choir from Uzhhorod performed during the funeral ceremonies (Duchnovič 1877, 57; Murín 1943, 37). The mortal remains of the first Greek Catholic bishop of Prešov rest in the crypt in the Cathedral of Saint John the Baptist in Prešov.

\section{REFERENCES}

\section{Primary sources}

Archív gréckokatolíckeho arcibiskupstva v Prešove - AGAP (Archive of the Greek Catholic Archeparchy in Prešov); collection (abbreviated to c.) Listiny, inventory number (inv. no.) 1 , box 1., signature (sign.) 8806.

AGAP, c. Listiny, inv. no. 6, sign. 137.

AGAP, c. Bežná agenda (BA), year 1822, inv. no. 338, sign. 628.

AGAP, c. BA, year 1822, inv. no. 338, sign. 404.

AGAP, c. BA, year 1822, inv. no. 338, sign. 691.

AGAP, c. BA, year 1824, inv. no. 341, sign. 300.

AGAP, c. BA, year 1824, inv. no. 340, sign. 824.

AGAP, c. BA, year 1826, inv. no. 342, sign. 1153.

AGAP, c. BA, year 1827, inv. no. 343, sign. 1321.

AGAP, c. BA, year 1828, inv. no. 345, sign. 768.

AGAP, c. BA, year 1838, inv. no. 454, sign. 442.

AGAP, c. Košický vikariát (KV), inv. no. 90, sign. 168.

Archív centra spirituality Východ - Západ M. Lacka - ACS VZ (Archive of the East - West

Spirituality Center M. Lacko), no sign. Decree of Pope Pius VII, dated June 13, 1802.

ACS VZ, no sign. Circular letter of Bishop G. Tarkovič, dated October 2, 1821.

ACS VZ, no sign. Circular letter of Bishop G. Tarkovič, dated October 5, 1822.

ACS VZ, no sign. Circular letter of Bishop G. Tarkovič, dated April 10, 1824.

ACS VZ, no sign. Circular letter of Bishop G. Tarkovič, dated July 22, 1825.

ACS VZ, no sign. Circular letter of Bishop G. Tarkovič, dated July 7, 1827.

ACS VZ, no sign. Circular letter of Bishop G. Tarkovič, dated October 2, 1821 and July 29, 1829. ACS VZ, no sign. Circular letter of Bishop G. Tarkovič, dated December 1, 1836.

ACS VZ, no sign. Letter from Bishop Tarkovič to Bishop Š. Čech, dated May 9, 1829.

\section{Secondary sources}

Babjak, Ján 1997. P. Michal Lacko, SJ - informátor a formátor gréckokatolíkov. Trnava.

Bidermann, Hermann Ignaz. 1867. Die ungarischen Ruthenen ihr Wohngebiet, ihr Erwerb u. ihre Geschichte. Innsbruck.

Coranič, Jaroslav 2018. Dvesto rokov od kánonického erigovania Prešovského gréckokatolíckeho biskupstva (22. september 1818). In Historia Ecclesiastica, IX/1, 94-114. 
Duchnovič, Alexander 1877. Chronologičeskaja istoria slavnoj eparchii Prjaševskoj ot jeja načala do pervaho episkopa Grigorija Tarkoviča. Sankt Peterburg.

Hetényi, Martin 2019. Cyrilo-metodský kult a religiozita na Slovensku v 19. - 21. storočí [The Cyrillo-Methodian Cult and Religiosity in Slovakia from the 19th to the 21st Century]. In Konštantínove listy [Constantine’s Letters] 12/1, 141-158.

Kubinyi, Julius 1970. The History of Prjašiv Eparchy. Romae.

Lacko, Michal 1982. Z našej minulosti: Biskup Gregor Tarkovič. In Mária 10, 14-15.

Lacko, Michal 1982. Z našej minulosti: Vznik Prešovského biskupstva. In Mária 8 - 9, 21-22.

Lehotská, Darina 1972. Príručka diplomatiky. Bratislava.

Líška, Anton 2012. Cholerová epidémia z roku 1831 a jej priebeh v Prešovskej eparchii. Prešov.

Malý, Karel - Sivák, Florián 1992. Dejiny štátu a práva v Česko-Slovensku do roku 1918. Bratislava.

Murín, Ján 1943 Dejiny gréckokatolíckeho biskupstva Prešovského za prvých dvoch biskupov (1787 - 1876). Dissertation thesis. Manuscript. Michalovce.

Pekar, Athanasius 1968. Historic Background of the Eparchy of Prjashev. Pittsburgh.

Pekar, Athanasius 1967. Narysy istorii Cerkvi Zakarpatta. Romae.

Pekar, Athanasius 1971. Alexander Duchnovic. The history of the eparchy of Prjasev. Romae.

Pirigyi, Istvan 1990. A magyaországi görög katolikusok törtenete II. kötet. Nyíregyháza : Görög Katolikus Hittudományi Főiskola Nyíregyháza.

Prvý prešovský biskup Gregor Tarkovič (1817 - 1841) 1989. In Gréckokatolícky kalendár 1989. Trnava, 90-93.

Ruby, Josephus 1903. Brevis historia dioecesis Eperjesiensis II. In Schematismus venerabilis cleri graeci ritus catholicorum dioecesis Eperjesiensis pro anno domini 1903. Eperjesini, 3-41.

Schematismus Venerabilis Cleri Graeci Ritus Catholicorum Dioecesis Eperiessiensis pro anno Domini 1823. Cassoviae.

Schematismus Venerabilis Cleri Graeci Ritus Catholicorum Dioeceseos Fragopolitanae pro anno Domini 1931. Fragopoli.

Špirko, Jozef 1943. Cirkevné dejiny s osobitným zretelom na vývin cirkevných dejín Slovenska, sväzok II. Turčiansky Sv. Martin.

Šturák, Peter 1999. Dejiny gréckokatolíckej cirkvi v Československu v rokoch 1945 - 1989. Prešov. Valčo, Michal - Slivka, Daniel et al. (eds.) 2012. Christian Churches in Post-Communist Slovakia: Current Challenges and Opportunities. Salem.

Vasil,' Cyril 2000. Kanonické pramene byzantsko-slovanskej katolíckej cirkvi v Mukačevskej a Prešovskej eparchii. Trnava.

Welykyj, Athanasius 1954. Documenta Pontificorum Romanorum historiam Ucrainae illustrantia (1700 - 1953), vol. II. Romae.

Zouhar, Jakub 2018. An Outline of Greek Catholic Monasticism in the Czech Lands and Czechoslovakia throughout the 19th and 20th Century. In Konštantínove listy [Constantine's Letters] 11/2, 151-167.

doc. PhDr. Jaroslav Coranič, PhD.

Department of Historical Sciences

Faculty of Greek Catholic Theology

Prešov University in Prešov

Street biskupa Gojdiča 2

08001 Prešov

Slovakia

jaroslav.coranic@unipo.sk 